\title{
Improving Fuel Efficiency and Reducing Carbon Emissions from Buses in India
}

\author{
Sudhir Gota \\ Parthaa Bosu and Sameera Kumar Anthapur, Clean Air Asia
}

\begin{abstract}
There is a growing public transport crisis in India, with a tremendous increase in the number of private vehicles. Many public bus corporations are operating with net financial losses and rely on government subsidies to keep operations going; therefore, investment in new buses and technology upgrades is rare. Of the various expenditures that bus corporations incur, fuel costs account for 30 percent. There is a strong need to improve fuel efficiency of buses to not only improve the financial viability of the bus companies but also to reduce their environmental and related health impacts. This study analyzes data on more than 500 buses from 3 leading bus corporations in India and identifies measures that can be implemented to improve fuel efficiency and reduce emissions.
\end{abstract}

\section{Introduction: Status of Bus Transport in India}

In Asia, growing income and increasing investments in the transport sector, especially in infrastructure, are translating into exploding growth in both urban and intercity transport activities, with rapid increases in motorization levels. In India, vehicle registrations increased from 1.8 million in the early 1970s to more than 100 million in 2008 (Ministry of Road Transport and Highways 2008). Two-wheelers and cars constitute more than 85 percent of registered vehicles. In 2008, buses represented only 1.3 percent of registered vehicles, a substantial drop from 11 percent in 1960s (Ministry of Urban Development 2008).The Ministry of Urban Development (MOUD) report (2008) compared the public transport trips for six different city types based on population and found a decrease in all of them, ranging from $20-72$ percent.

The majority of the Indian bus fleet is held by private bus operators, who are not formally organized. The organized sector of the bus industry - the State Road Transport Undertakings (SRTUs) - is supported by the government under the Road Transport Corporation (RTC) Act of 1950 and accounts for only 8 percent of the national bus fleet based on vehicle registrations. Data for bus transport exist only for this 8 percent of the bus fleet. In 2010, the SRTUs carried 70 million passengers per day, generating about 501 billion passenger kilometers ( $\mathrm{pkm}$ ) annually, and approximately 95 percent of these passenger kilometers represent intercity travel. (Report of the Sub Group on State Road Transport Undertakings). 
In 2006, the Indian Government formulated the National Urban Transport Policy (NUTP) with a view to provide better transport facilities. The policy was supported by the launch of Jawaharlal Nehru National Urban Renewal Mission (JNNURM), which facilitated the funding for urban services, including transport. Recognizing that organized bus transport services were available in only 24 Indian cities in 2007 (Singh 2010), increasing the number and quality of buses was taken up as a priority. To further this objective, as part of a stimulus package in 2009, the Government of India provided financial incentives for bus purchases by municipal governments that implemented a set of prescribed reforms. The target was the procurement at least 15,000 new buses nationwide. According to the financing mechanism, cities with populations over 4 million (per Census 2001) were eligible for Central Government assistance equivalent to 35 percent of the total project costs. For cities with populations between 1 and 4 million, assistance was available for 50 percent, and for cities with less than 1 million, the share was 80 percent. This stimulus scheme resulted in visible increases in bus numbers in many cities between 2009 and 2011, but most of the public transport agencies are still in financial loss. In 2009-2010, only five state transport corporations had net annual profits, and the total combined losses of the 34 reporting SRTUs were more than 50.8 billion INR (Indian Rupee) or US $\$ 1.01$ billion (CIRT 2010). This issue is discussed in subsequent sections.

\section{Bus Carbon Emissions and Fuel Costs}

It is estimated that 20 percent of India's $\mathrm{CO}_{2}$ emissions from the transportation sector are from buses (Clean Air Asia 2012). Further, it has been estimated that if the current trip mode share of public transport is retained, $\mathrm{CO}_{2}$ emissions will increase two- or three-fold between 2008 and 2025 due to a rapid growth in urban population and an increase in the number of trips (Fabian and Gota 2009).

Buses accounted for 12 percent of the total diesel consumption in India in 2008-2009 (Government of India 2010) and were a significant contributor to urban air pollution (Clean Air Asia 2012, CPCB 2011, Fabian and Gota 2009). Fuel cost is about 30 percent of the total expenses for Indian bus companies (ownership, management, maintenance, employees, etc). Over the past decade, the fuel cost per kilometer of bus travel has increased from INR 3.64 in 2000 to INR 7.24 in 2009 (CIRT 2010, 7) in spite of slight improvements in fuel efficiency of the buses (CIRT 2010). With the partial deregulation of diesel prices in 2013, the expenditure on fuel and, therefore, per-kilometer cost will tend to increase further, assuming the fuel efficiency remains the same or continues to reduce. Improvements in fuel efficiency can improve a bus company's financial viability and reduce environmental and related health impacts associated with bus transport.

\section{Objective}

The objective of this research was to investigate the potential for improving fuel efficiency and reducing $\mathrm{CO}_{2}$ emissions of Indian bus fleets.

\section{Methodology}

The focus of this research was an understanding of bus operation and management practices by collecting and analyzing operational data to determine improvement measures. 
The bus corporations chosen were of both intercity and urban operations and consisted of different types of buses in emission standards, manufacturer types, models, etc. All three bus corporations-Bangalore Metropolitan Transport Corporation (BMTC), Karnataka State Road Transport Corporation (KSRTC), and State Express Transport Corporation (SETC) - are recognized as top performers in the country in the areas of finance, application of best practices, adoption of new technology, high efficiency, and patronage. Therefore, insights from these organizations should ideally set a benchmark for the rest of the industry. A questionnaire based on the 2011 Energy Sector Management Assistance Program (ESMAP) study was developed to capture management insights and was incorporated into the toolkit as an intervention measure. The responses were captured in one-on-one meetings with top management. A multi-stakeholder approach was then adopted for consultations with key bus industry, public transport agencies, government officials, research institutions, and non-government organizations to discuss the data and develop the recommendations.

\section{Insights from Data Analysis}

Detailed operational and maintenance data from more than 500 buses was collected. Data from a period of one year was collected for each of the buses. The analysis was conducted by grouping bus data by depot, as each depot had the same bus manufacturer, and then grouping data by the emission standards the buses were designed to meet.

TABLE 1.

Data Collected from

Bus Operators

\begin{tabular}{|c|l|}
\cline { 2 - 2 } \multicolumn{1}{c|}{} & \multicolumn{1}{c|}{ Parameter } \\
\hline 1 & Bus registration number \\
\hline 2 & Year of manufacture \\
\hline 3 & Fuel type \\
\hline 4 & Manufacturer (company) \\
\hline 5 & Bus type (low floor, standard) \\
\hline 6 & AC or non-AC \\
\hline 7 & Operation (city, intercity) \\
\hline 8 & Total carrying capacity \\
\hline 9 & Fuel consumed per year (kilo liters) \\
\hline 10 & Effective km per year \\
\hline 11 & Dead km per year \\
\hline 12 & Days used per year \\
\hline 13 & Average speed, peak hour (kmph) \\
\hline 14 & Average speed, non-peak hour (kmph) \\
\hline 15 & Average occupancy, peak hour \\
\hline 16 & Average occupancy, non-peak hour \\
\hline 17 & Total ridership per year \\
\hline 18 & Total idling time per day (min) \\
\hline 19 & Number of trips per day \\
\hline 20 & Average trip length (km) \\
\hline & \\
\hline
\end{tabular}


From the data collected under the parameters in Table 1, the summary of the indicators developed is shown in Table 2.

TABLE 2.

\begin{tabular}{|l|r|r|r|}
\hline \multicolumn{1}{|c|}{ Parameters } & BMTC & \multicolumn{1}{c|}{ KSRTC } & \multicolumn{1}{c|}{ SETC } \\
\hline Number of buses & 185 & 312 & 52 \\
\hline Average fuel efficiency (kmpl) & 3.77 & 4.28 & 5.04 \\
\hline Number of days used per year & 312 & 334 & 260 \\
\hline Bus utilization per day (km) & 225 & 432 & 692 \\
\hline Average passengers per bus on road per day & 504 & 281 & 85 \\
\hline Passenger load factor (\%) & 104 & 70 & 76 \\
\hline Total passenger-kilometers (M) & 747 & 1475 & 288 \\
\hline Average passenger lead (avg. distance traveled by passenger, km) & 25.85 & 313 & 294 \\
\hline Dead kilometers (00,000) & 1.07 & 8.38 & 1.01 \\
\hline Gross bus utilization/year (00,000) & 0.7 & 1.41 & 1.81 \\
\hline Average speed (kmph) & 40 & 48 & 67 \\
\hline Average effective km (\%) & 99.1 & 98 & 98.9 \\
\hline Average dead km (\%) & 0.86 & 2 & 1.1 \\
\hline Average age of bus (yr) & 6.26 & 3.29 & 4.02 \\
\hline Scrapping limit (yr) & 10 & 8 & 10 \\
\hline Number of over-age buses & 15 & 4 & 0 \\
\hline Average idling time (min) & 34 & 45 & 43 \\
\hline
\end{tabular}

BMTC = Bangalore Metropolitan Transport Corporation

KSRTC $=$ Karnataka State Road Transport Corporation

SETC $=$ State Express Transport Corporation

There is a perception among industry experts and fleet managers that introducing new buses with improved emission standards causes a substantial decrease in the fuel efficiency of buses, thus lowering the fleet fuel efficiency. However, as shown in Table 3 and based on our analysis, it was found that old buses with lower emissions standards are experiencing lower fuel efficiency when compared with newer buses. Data from all the three agencies substantiate this argument, except in the case of Euro I of BMTC. The deterioration of buses due to extensive use over the years dominates the impact of fuel efficiency reductions due to emissions standard improvement. So, as a new bus replaces an older bus, it would be incorrect to assume that the fuel efficiency of buses would be reduced. 
TABLE 3.

Kilometers Traveled and Fuel Consumed Based on Emissions Standards

\begin{tabular}{|c|l|c|c|c|c|}
\hline Agency & Bus Type & $\begin{array}{c}\text { Year of } \\
\text { Manufacture }\end{array}$ & $\begin{array}{c}\text { Fuel Consumed } \\
\text { (kilo liters) }\end{array}$ & $\begin{array}{c}\text { Vehicle km } \\
\text { Traveled (km) }\end{array}$ & $\begin{array}{c}\text { Fuel Efficiency } \\
\text { (kmpl) }\end{array}$ \\
\hline \multirow{4}{*}{ BMTC } & Euro IV & $>2010$ & 117 & 517,940 & 4.43 \\
\cline { 2 - 6 } & Euro III & $2006-2010$ & 2,022 & $6,886,458$ & 3.41 \\
\cline { 2 - 6 } & Euro II & $2002-2005$ & 895 & $3,870,036$ & 4.33 \\
\cline { 2 - 6 } & Euro I & $2000-2001$ & 355 & $1,629,026$ & 4.59 \\
\hline \multirow{3}{*}{ KSRTC } & Euro III & $2006-2010$ & 5,402 & $23,396,049$ & 4.33 \\
\cline { 2 - 6 } & Euro II & $2002-2005$ & 4,773 & $20,193,029$ & 4.23 \\
\cline { 2 - 6 } & Euro I & $2000-2001$ & 135 & 497,667 & 3.68 \\
\hline \multirow{2}{*}{ SETC } & Euro III & $2006-2010$ & 149 & 832,369 & 5.60 \\
\cline { 2 - 6 } & Euro II & $2002-2005$ & 1,722 & $8,554,555$ & 4.97 \\
\hline
\end{tabular}

$B M T C=$ Bangalore Metropolitan Transport Corporation KSRTC $=$ Karnataka State Road Transport Corporation SETC $=$ State Express Transport Corporation

TABLE 4.

Variation of Fuel Efficiencies among Fleets

\begin{tabular}{|l|c|c|c|c|}
\hline \multicolumn{1}{|c|}{ Agency/Type } & Highest $\mathbf{( k m p l )}$ & Lowest $\mathbf{( k m p l )}$ & Average (kmpl) & \# Buses \\
\hline BMTC Non-AC & 5.33 & 3.88 & 4.38 & 160 \\
\hline BMTC AC & 1.99 & 1.56 & 1.70 & 25 \\
\hline KSRTC Non-AC & 5.68 & 4.38 & 5.23 & 159 \\
\hline KSRTC AC & 4.84 & 3.22 & 3.73 & 153 \\
\hline SETC Non-AC & 5.82 & 5.1 & 5.31 & 42 \\
\hline SETC AC & 3.94 & 3.59 & 3.85 & 10 \\
\hline
\end{tabular}

BMTC = Bangalore Metropolitan Transport Corporation KSRTC = Karnataka State Road Transport Corporation SETC $=$ State Express Transport Corporation

There exists a substantial difference in fuel efficiency of the buses among different depots within a single agency in a city. Traffic characteristics do not vary significantly among depots within a city and, thus, this points towards establishing a need for having a standardized maintenance code and practices and rewarding depots that achieve higher fleet fuel efficiency values.

FIGURE 1.

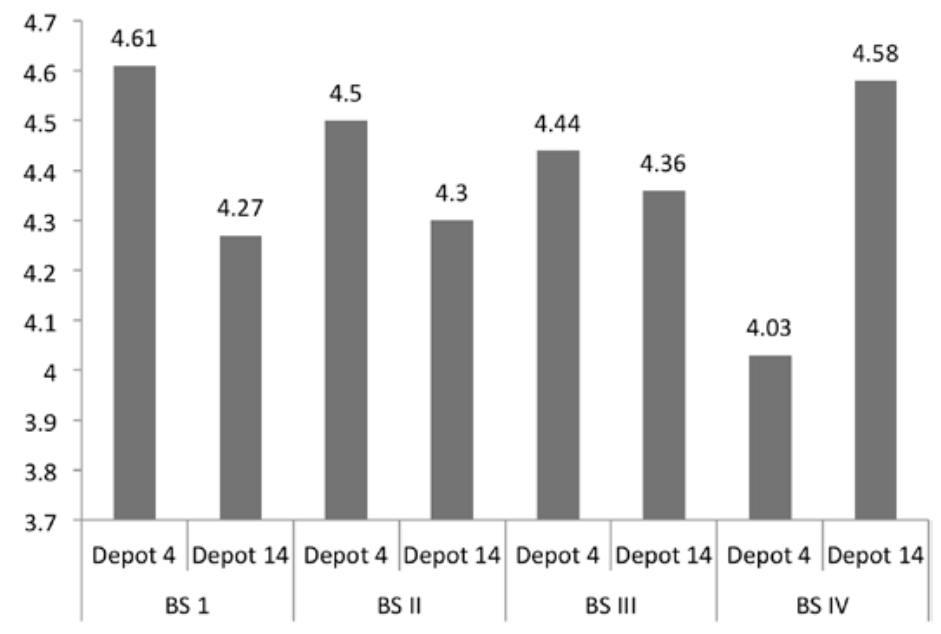


A questionnaire was designed to evaluate the commitment of the agencies in improving fuel efficiency of the buses and maintenance practices. A set of 19 questions was discussed with top management of the agencies, and the results are summarized in Table 5.

TABLE 5.

Questionnaire for Management on Fuel Efficiency Initiatives

\begin{tabular}{|c|c|c|c|c|}
\hline & Fuel Economy Scorecard for Current Bus Fleet & BMTC & KSRTC & SETC \\
\hline \multirow[t]{6}{*}{$\begin{array}{l}\text { I. Management } \\
\text { commitment } \\
\text { and ownership }\end{array}$} & $\begin{array}{l}\text { 1. Is there a senior executive in charge of fleet fuel economy, } \\
\text { and is some part of his/her bonus tied to meeting fuel economy } \\
\text { goals? }\end{array}$ & No & No & No \\
\hline & $\begin{array}{l}\text { 2. Do you benchmark and set appropriate fuel economy goals } \\
\text { by bus type for each year? }\end{array}$ & No & Yes & Yes \\
\hline & $\begin{array}{l}\text { 3. Do you communicate the fuel economy results achieved } \\
\text { each year to both employees and the public to create an } \\
\text { environment-friendly brand? }\end{array}$ & Yes & No & No \\
\hline & 4. Is a strategy to replace old buses actively pursued? & No & No & Yes \\
\hline & $\begin{array}{l}\text { 5. Is a policy to improve the speed of the buses actively } \\
\text { pursued? }\end{array}$ & No & No & No \\
\hline & 6. Is a strategy to reduce idling and emissions actively pursued? & No & No & No \\
\hline \multirow[t]{5}{*}{$\begin{array}{l}\text { II. Data } \\
\text { collection and } \\
\text { analysis }\end{array}$} & $\begin{array}{l}\text { 7. Is the data collection process automated to the extent } \\
\text { feasible, and do you use analysis software to support } \\
\text { maintenance? }\end{array}$ & No & No & No \\
\hline & 8. Have you set up data quality assurance procedures? & No & No & No \\
\hline & $\begin{array}{l}\text { 9. Do you analyze the data for separating the effects of driver, } \\
\text { route and bus-related effects on fuel economy? }\end{array}$ & Yes & Yes & Yes \\
\hline & $\begin{array}{l}\text { 10. Do you use a GPS or a black box to collect data on driver } \\
\text { behavior and infrastructure routing? }\end{array}$ & No & No & No \\
\hline & 10a. Do you use data to refine periodic maintenance? & Yes & Yes & Yes \\
\hline \multirow[t]{7}{*}{ III. Maintenance } & $\begin{array}{l}\text { 11a. Do you select at least } 10 \% \text { of the fleet showing the lowest } \\
\text { fuel economy and conduct simple checks at depots? }\end{array}$ & Yes & Yes & Yes \\
\hline & $\begin{array}{l}\text { 11b. Do you conduct detailed checks at the central facility if the } \\
\text { bus passes step 11a to determine the issues? }\end{array}$ & Yes & Yes & Yes \\
\hline & $\begin{array}{l}\text { 11c. Do you compare pre- and post-repair fuel economy data on } \\
\text { these buses to estimate program benefits? }\end{array}$ & Yes & Yes & Yes \\
\hline & 12. Do you check repair quality on a random and periodic basis? & Yes & Yes & Yes \\
\hline & 13. Do you obtain mechanic sign-off on repairs for traceability? & Yes & Yes & Yes \\
\hline & $\begin{array}{l}\text { 14. Do you conduct an independent team audit of repairs across } \\
\text { depots? }\end{array}$ & No & No & No \\
\hline & $\begin{array}{l}\text { 15. Do you retrain mechanics and update repair procedures } \\
\text { periodically? }\end{array}$ & Yes & Yes & Yes \\
\hline \multirow{2}{*}{$\begin{array}{l}\text { IV. Training of } \\
\text { low-performing } \\
\text { drivers }\end{array}$} & $\begin{array}{l}\text { 16. Do you train drivers on fuel-efficient driving techniques and } \\
\text { periodically retrain them? }\end{array}$ & Yes & Yes & Yes \\
\hline & $\begin{array}{l}\text { 17. Do you select at least } 10 \text { percent of drivers with the lowest } \\
\text { fuel efficiency and conduct special additional training? }\end{array}$ & Yes & Yes & Yes \\
\hline \multirow{2}{*}{$\begin{array}{l}\text { V. Employee } \\
\text { communications } \\
\text { and rewards }\end{array}$} & $\begin{array}{l}\text { 18. Do you publicly display the fuel economy performance by } \\
\text { driver and bus depot to employees? }\end{array}$ & No & No & No \\
\hline & $\begin{array}{l}\text { 19. Do you reward mechanics at the depot level and drivers } \\
\text { individually for exceeding targets? }\end{array}$ & No & Yes & Yes \\
\hline
\end{tabular}

BMTC = Bangalore Metropolitan Transport Corporation

KSRTC = Karnataka State Road Transport Corporation

SETC $=$ State Express Transport Corporation 
It was found that agencies do not prioritize the automated data collection process (question 7) to understand driver behavior and use the data to train drivers, although analysis of the data is conducted to study the impact on driver, route, and bus. Some of the other learnings that emerged in this process are the following:

- Top management is not directly held responsible for ensuring improvement in fuel efficiency.

- There is no strategy to reduce emissions.

- Maintenance works are recorded and documented.

- Driver and mechanic training is given emphasis to get the best out of them.

- Fuel economy targets and achievements are not well-publicized internally and externally.

It was observed that due to factors such as congestion and route, the variation in annual distance traveled by different buses was very high, with a range of 10,000-230,000 km/ year. Due to operational issues, such as lack of adequate buses, many fuel "guzzlers" were used for greater distances when compared to more efficient buses. Ideally, low fuel-efficient buses should not be used to travel longer distances per day, while buses with higher fuel efficiencies should be used to travel more kilometers per day to optimize the fuel efficiency of the fleet.

FIGURE 2.

Fuel efficiency target of $5.50 \mathrm{kmpl}$ displayed prominently at a depots

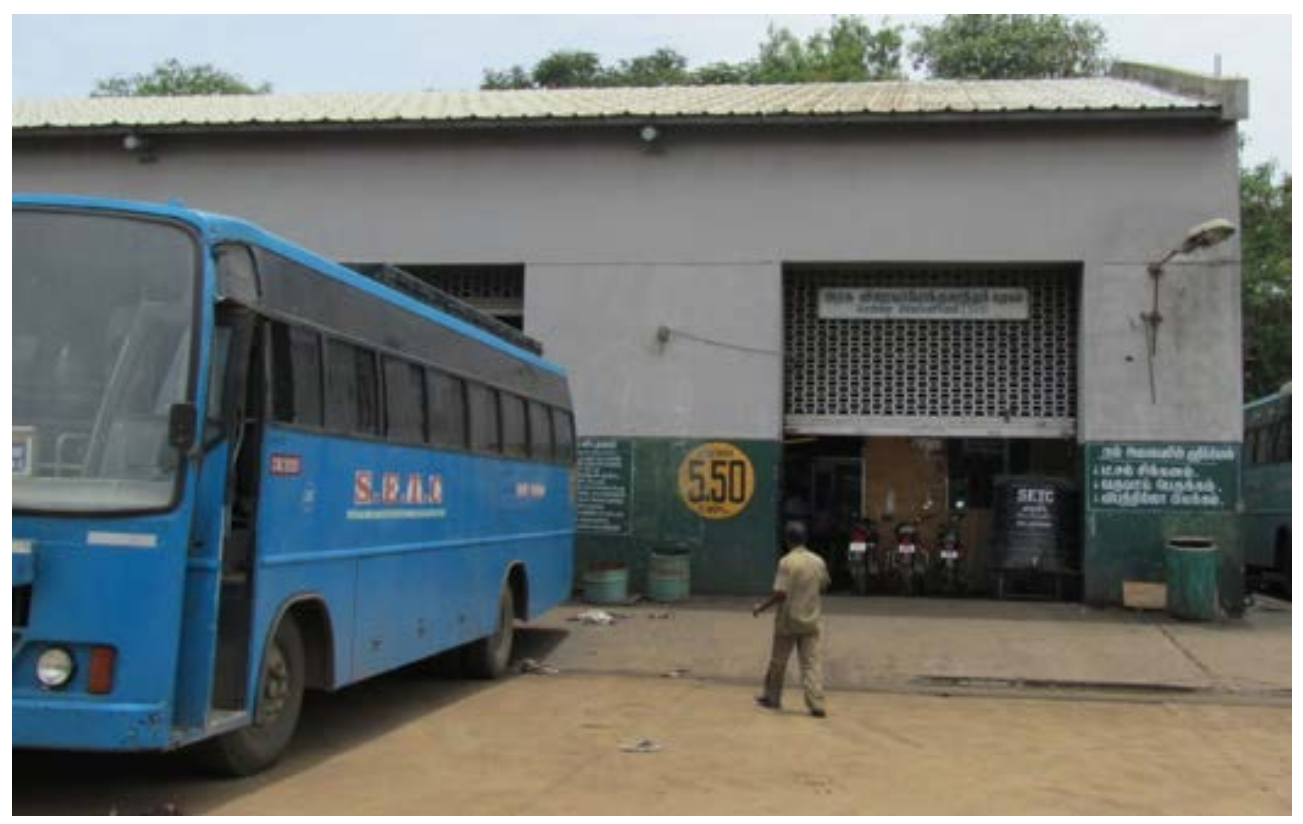

The table provided in the tool ranks the under-utilized and over-utilized buses, which enable a fleet owner to rationalize the bus routes based on fuel efficiency. By reorienting the buses - that is, using high fuel-efficient buses along routes with higher activity-significant savings can be generated. It is calculated that by identifying and rerouting 20 buses, more than $\$ 30,000$ USD could be saved in a year. Ideally, the more the fuel efficiency of a bus, the higher should be the activity. For example, in the case of Depot 14 of 
BMTC, the over-utilized buses did an average of $287 \mathrm{~km}$ per day while the under-utilized buses did $233 \mathrm{~km}$ per day (Table 6). This is a significant observation, as traffic characteristics do not radically alter within a depot influence area.

TABLE 6.

Bus Utilization vs. Fuel Efficiency

\begin{tabular}{|c|c|c|c|c|c|c|}
\hline \multirow[b]{2}{*}{$\begin{array}{l}\text { For } 20 \text { over-utilized and under-utilized } \\
\text { buses data }\end{array}$} & \multicolumn{2}{|c|}{ BMTC } & \multicolumn{2}{|c|}{ KSRTC } & \multicolumn{2}{|c|}{ SETC } \\
\hline & $\begin{array}{l}\text { Over- } \\
\text { utilized }\end{array}$ & $\begin{array}{l}\text { Under- } \\
\text { utilized }\end{array}$ & $\begin{array}{l}\text { Over- } \\
\text { utilized }\end{array}$ & $\begin{array}{l}\text { Under- } \\
\text { utilized }\end{array}$ & $\begin{array}{l}\text { Over- } \\
\text { utilized }\end{array}$ & $\begin{array}{l}\text { Under- } \\
\text { utilized }\end{array}$ \\
\hline Average fuel efficiency ( $\mathrm{km} /$ liter) & 3.65 & 4.82 & 3.50 & 5.52 & 5.03 & 5.41 \\
\hline Total km/bus/day & 270 & 183 & 711 & 230 & 727 & 686 \\
\hline Fleet avg. km/bus/day & \multicolumn{2}{|c|}{225} & \multicolumn{2}{|c|}{432} & \multicolumn{2}{|c|}{692} \\
\hline
\end{tabular}

An hour of idling for a bus consumes almost two liters of fuel (Clean Air Asia 2012). Based on the data analyzed, it was observed that, on an average, idling resulted in consumption of more than 1.2 liters of fuel per day per bus (Table 7). This was very high, as very few buses were air-conditioned, thus indicating poor driving practices. The main reason suggested by drivers was lack of confidence in restarting the buses on the congested roads and junctions or, in the case of intercity air-conditioned buses, the buses had to be kept on to keep the air-conditioner working.

TABLE 7.

Average Idling Time and its Impact on Fuel Consumption

\begin{tabular}{|l|c|c|c|}
\cline { 2 - 4 } \multicolumn{1}{c|}{} & BMTC & KSRTC & SETC \\
\hline Avg. idling time (min) & 34 & 45 & 43 \\
\hline Fuel impact per bus per day (Itr) & 1.2 & 1.4 & 1.1 \\
\hline
\end{tabular}

BMTC = Bangalore Metropolitan Transport Corporation KSRTC = Karnataka State Road Transport Corporation SETC $=$ State Express Transport Corporation

There is a non-linear relationship between speed and fuel consumed. The ideal speed or speed at which maximum fuel efficiency is obtained depends on each vehicle class; for buses, it is approximately in the range of $55-60 \mathrm{kmph}$ (Asian Development Bank and Ministry of Transport 2009). Beyond that speed, aerodynamic resistance is very high, thereby reducing fuel efficiency. However, emphasis on the speed impact on fuel efficiency is not given much importance. If the average speed of buses can be increased through interventions such as bus rapid transit (BRT), transit signal priority (TSP), exclusive bus lanes, high-occupancy vehicle lanes, etc., significant fuel savings can be achieved. It has been estimated that if the bus speed can be increased from $15 \mathrm{kmph}$, which is the average bus speed in city conditions in India (Bangalore Traffic Improvement Project B-TRAC 2010), to $20 \mathrm{kmph}$, a nearly 25 percent improvement in fuel efficiency could be observed, resulting in a saving of 4,000 liters of fuel per year per bus (Asian Development Bank and Ministry of Transport 2009).

By replacing some of the older buses, which have high emissions and are beyond productive life, with new buses, fleet emissions can be reduced. The average age of the fleets was around five years, and nearly seven percent of the buses were found to have exceeded the scrapping limit set by the respective agencies (as seen in Table 2) but still were being 
used due to lack of resources to purchase new buses and high public transport demand. With the introduction of newer buses that meet BS IV standards (equivalent to Euro IV), emissions are greatly reduced, since newer buses adhere to stricter emission norms. For example, by scrapping 15 ordinary buses that are 11-15 years old and by introducing 15 new buses, Particulate Matter (PM) savings of 2.19 tons per year and NOx savings of 27.54 tons per year can be achieved. Along with reduced emissions, one can also ensure greater productivity (more than 2,000km/year) due to fewer repairs, breakdowns, and maintenance issues from new buses.

\section{Recommendations}

Based on the analysis of the sample data and the literature survey, it was observed that a 10 percent increase in fuel efficiency can be easily targeted by initiating several measures.

- Fuel Economy Targets - Bus operators need to be engaged in setting fuel efficiency targets for their fleets and monitoring the impact. For example, national level targets or key performance indicators (KPI) for buses/fleets on road should be designed for different types of buses and buses operating in different regions. A branding scheme such as a star rating system could be established. Buses/fleets satisfying the standards could be branded and incentives could be packaged. This kind of initiative can be undertaken only with regulatory, legal, and institutional support. A good example of this is China's proposed Green Freight Initiative scheme for awarding truck operators or its Green and Yellow label for vehicles based on emissions standards (Ministry of Environmental Protection, China 2009). It was found that by mandating fuel efficiency targets, making top management responsible for achieving the targets, collecting scientific data, and conducting training, 3-5 percent fuel efficiency improvements can be achieved (ESMAP 2011).

- Branding - Buses need to go beyond a brand "logo." The Ministry of Road Transport and Highways, which is the national ministry responsible for transport in India, needs to take an active lead in designing and implementing a communication strategy on Clean Buses. The vision of such a strategy should be that the public image of bus transforms from "dirty buses" to "clean/green buses." One of the strongest reasons branding exercises need to be done is to bring bus transport to people's attention and project it as a friendly, safe, and reliable mode. One example of bus communication and branding is "Bus Day" organized by BMTC on the 4th of every month.

- Capacity Building - National training should be conducted for drivers, mechanics, and operators to improve bus repair, bus maintenance, and driver behavior. Universities and research institutions need to take a lead in developing and providing a national mid-level management training program on optimizing, routing, scheduling, and synchronizing of bus movements. Bus manufacturers can play an important role in training mechanics and drivers. Current training methods adopted are not scientific and are carried out on old buses with different technologies.

- Data - Currently, the Central Institute of Road Transport in India collates and publishes the performance data on State Transport Undertakings (STUs). There is need to include bigger private bus companies in such annual reviews so that 
adequate comparison can be made and insights drawn. The annual reporting needs to be compulsory, and guidelines for data collection need to be developed. The data collection process for distance, fuel consumption, and driving behavior needs to be updated and automated as much as possible. Annual monitoring of fuel efficiency values should be linked with incentives for good performers (awards or subsidy).

- Finance - An appropriate microfinance/revolving fund/subsidy scheme should be designed to target gross polluters using strategies such as technology retrofit, repairmaintenance, repower, and replace.

- Urban Participation - Fuel efficiency measures are directly linked with landuse, ridership improvement, speed improvement, and accessibility improvement measures. Bus agencies, unfortunately, do not have direct control on many of such variables and, thus, improving fuel economy measures needs to go beyond buses. Bus operators need to play an active role as important stakeholders in urban transport issues and ensure that the city transport system supports the buses as much as the buses support the city transport system.

- Technology - Smart technologies such as signal prioritization can be a solution to reduce junction idling. By installing wider doors, faster ingress and egress can be achieved, resulting in reduced idling at bus stops. By constructing exclusive lanes, idling related to congestion and traffic jams can be reduced.

\section{References}

Asian Development Bank and Ministry of Transport, People's Republic of China. 2009. Green transport resource optimization, Volume 2.

Bangalore Traffic Improvement Project B-TRAC. 2010. http://www.bangaloretrafficpolice. gov.in/index.php?option $=$ com_content $\& v i e w=$ article\&id $=57 \& b t p=57$. Accessed May 28, 2013.

Central Institute of Road Transport (CIRT). 2010. State transport undertakings-Profile and performance 2009-10.

Central Pollution Control Board (CPCB). 2011. Air quality monitoring, emission inventory and source apportionment study for Indian cities. National Summary Report. http:// www.cpcb.nic.in/FinalNationalSummary.pdf. Accessed May 15, 2013.

Clean Air Asia. 2012. Accessing Asia: Air pollution and greenhouse gas emissions indicators for road transport and electricity. http://www.baq2012.org/assets/Uploads/ Accessing-Asia22Nov2012-FINAL-FOR-PRINT.pdf, accessed May 16, 2013.

Clean Air Asia. 2012. Green Trucks Toolkit. http://cleanairinitiative.org/portal/greentruckstoolkit, accessed May 16, 2013.

ESMAP. 2009. Guidance note best operational and maintenance practices for city bus fleets to maximize fuel economy. http://www.esmap.org/sites/esmap.org/files/ FINAL_EECI-BusGuideNote_BN010-11.pdf, accessed May 25, 2013. 
Fabian, B., and Gota, S. 2009. Emissions from India's intercity and intracity road transport. http://cleanairinitiative.org/portal/sites/default/files/articles-73353_resource_1.pdf, accessed May 16, 2013.

Government of India. 2010. Report of the expert group on a viable and sustainable system of pricing of petroleum products. http://petroleum.nic.in/reportprice.pdf, accessed May 14, 2013.

Government partially deregulates diesel prices, hikes LPG cap. Zee News, January 18, 2013. http://zeenews.india.com/business/news/economy/govt-partially-deregulates-diesel-prices-hikes-lpg-cap_68315.html, accessed May 28, 2013.

Institution of Transportation Policy Studies (ITPS). 2009. A study of mid/long-term railway networks.

Ministry of Environmental Protection, The People's Republic of China. 2009. http:// english.mep.gov.cn/News_service/news_release/200908/t20090817_157507.htm, accessed May 26, 2013.

Ministry of Road Transport and Highways, Government of India. 2008. http://morth.nic. in/, accessed May 13, 2013.

Ministry of Urban Development, Government of India. 2008. Study on traffic and transportation policies and strategies in urban areas in India. http://www.urbanindia.nic. in/programme/ut/final_report.pdf, accessed May 1, 2013.

Ministry of Urban Development, Government of India. Transforming city bus transport in India through financial assistance for bus procurement under JnNURM. http:// jnnurm.nic.in/wp-content/uploads/2012/02/booklet-on-transforming-City-BusTransport-in-India.pdf, accessed May 9, 2013.

Report of the Sub Group on State Road Transport. Undertakings formed under the Working Group on Road Transport Constituted by Planning Commission, Twelfth Plan 2012-2017. http://www.indiaenvironmentportal.org.in/files/file/Report percent20SRTUs.pdf, accessed May 15, 2013.

Singh, J. 2010. Bus system reform in India through initiative under JnNURM - A way forward towards sustainable public transport. http://www.slideshare.net/jaaaspal/ bus-system-reform-in-india-through-jnnurm, accessed May 10, 2013

United Nations Environment Program (UNEP). 2009. Cleaning up urban fleets. http:// www.unep.org/transport/pcfv/PDF/Retrofit.pdf, accessed May 15, 2013.

World Bank. 2006. Average unit road user costs. http://web.worldbank.org/WBSITE/ EXTERNAL/TOPICS/EXTTRANSPORT/EXTROADSHIGHWAYS/0,,contentMDK:20964930 menuPK:1097394 pagePK:148956 piPK:216618 theSitePK:338661 isCURL:Y isCURL:Y,00.html, accessed May 16, 2013. 


\section{Acknowledgments}

Mr. Sudhir would like to acknowledge support by the Lee Schipper Memorial Foundation/WRI Fund.

\section{About the Author}

SUDHIR GOTA (Sudhirgota@gmail.com) specializes in environmental issues related to transport and has extensive experience in transport data crunching and developing models and methodologies on transport emissions for different types of projects, policies, and investments. He has more than 10 years of experience in research and managing projects related to transportation and environment and is an active researcher. He has co-written a book on low carbon transport and several publications and policy briefs on transport and environmental issues challenging conventional practices and advocating innovative solutions.

PARThAA Bosu (Parthaa.bosu@cleanairasia.org) has more than 11 years of experience in corporate affairs and corporate communications. Moving from a transport company, he joined the Society of Indian Automobile Manufacturers (SIAM) in 2000 to look into in-use vehicle emissions before moving onto special projects and headed Corporate Communications. In 2009, he had a brief stint with the Organising Committee Commonwealth Games Delhi 2010 and was instrumental in developing the first walkability survey application. He is a part of the working group on NMT promotion in the Ministry of Urban Development in India.

SAMEera KUmAR ANTHAPUR (Sameera.kumar@cleanairasia.org) is the Transport Researcher for the Clean Air Asia team in India and has an interest in NMT systems and policies. Previously, he worked in the transport sector in various capacities for more than five years, where he had wide exposure to project coordination, estimation, traffic surveys, analysis, documentation, signal design, and design of roads and NMT facilities. 